DOI https://doi.org/10.36059/978-966-397-108-7/65-81

\title{
STATE POWER AND LOCAL SELF-GOVERNMENT IN KIEVAN RUS
}

\section{Malchyn Yu. M.}

\section{INTRODUCTION}

Kievan Rus marked the beginning of the statehood in Eastern Slavs. This is the inception of own history of Ukraine in relation to both its statehood origins and self-government on the own land. This is the source from where we take positive and negative experiences of state-creation as well as local self-government organization in Ukraine.

The issue of both state power and local self-government will always be vital for scientific analysis because the state power has been and is the main means of the state policy as well as main instrument of state and personal interest implementation at all times. And local self-government, which appeared long before the statehood, is a regulator of internal group relations, which is inherent in the society, aimed at realizing their interests due to unification of public endeavors.

Human experience from ancient times to present proves that it is through the local self-government that the idea of power realization by people directly can be fully implemented into life, as well as the problem of interaction of the state, community and personality can be solved.

Kievan Rus gives us good lessons of prosperity and decline of the state. The examples are the roles of great princes in the state prosperity and separatist actions of appanage princes, local boyars and merchants in the weakening of the state, having led to its decline. The value of princes' personal qualities, their authority and the example for authority of power and state in the world community should be mentioned. The importance of regulating taxes and fees, making them feasible and acceptable to people, clearly determination of the tribute amount for the state and principality needs should be mentioned as well. The good example is how free assemblies of citizens (veche) are gradually coming under the influence of wealthy city dwellers and, in fact, serve their interests. And the boyars and merchants involved in the prince's administration, lobbying their interests, have strengthened separatist attitudes in the appanage principalities. 
Braichevsky M. Yu., Hrushevsky M. S., Doroshenko D., Poyuchevsky V.O., $\quad$ Krypiakevych I. P., $\quad$ Polonska-Vasilenko N., Solovyov C. M., Tolochko P. P., at al. devoted their works to the study of the state power and local self-government issue in Kievan Rus.

Their deep scientific studies comprehensively cover the historical period of the Kiev state, its prosperity and disintegration.

\section{State Power in Kievan Rus}

M. Hrushevsky dates the beginning of the state life in Ukraine back to the 12th century. He connects it with the trade development. Commercial caravans required armed protection from attackers on the land route as well as on the Dnipro. Only a certain organization could give such protection. So, the military leaders-princes together with their druzhina (a fellowship) appeared in the trade cities. This way, in his opinion, the state life begins to develop along with the trade development. ${ }^{1}$

From the middle of the 9th century, Kievan state gained fame for its campaign against Byzantium. It was a military campaign to Tsargrad. The "Tale of Bygone Years" describes how Askold and Dir destroyed the outskirts of the city in $866 .^{2}$

In foreign sources, fragmentary information about the state of Kievan Rus can be seen. In the middle of the 9th century, the Emperor of Byzantium, Konstantin Porphyrogenitus, recalled the treaty between Vasily I and Rus in 873-874 during the reign of Askold. At the same time, the first Raffelstetten customs regulations were created during the reign of Ludwig the German (876), which set the duty on goods transported from Rus to Bavaria. ${ }^{3}$

These and other facts prove the existence of a powerful state organization from the middle of the 9th century, namely, Kievan Rus, that subordinates neighbors, fights with Byzantium, concludes peace treaties with it as well as with other states. Based on the above mentioned, Russian historian V. Klyuchevsky reasonably concludes that "the Russian state was founded based on the activities of Askold and Oleg, and the unification of Slavs in the ancient state took place in Kiev, but not in Novgorod". 4

\footnotetext{
${ }^{1}$ М. Грушевський. Історія України-Руси. - К. Наукова думка,. 1992. - Т. І. - С. 388-398.

2 Повесть временных лет. - М - Л. - 1950. - С. 19.

${ }^{3}$ Полонська-Василенко Н. - К. Либыдь, 1992. - Т. 1. - С. 93.

${ }^{4}$ В. О. Ключевський. Курс русской истории. - М. - 1923. - Т. І. - С. 175.
} 
In 907, Oleg went to Tsargrad with a large army, burned its outskirts and made it sign very favorable treaties in 907-911. The treaties provided Oleg's druzhina and merchants with broad rights. In particular, they had to receive a detention for 6 months from the Greeks in Tsargorod. The Greeks had to provide them with sails and all the necessary equipment for boats as well as food for "their journey back home".

In the treaties with Russia the right to duty free trade was recognized. Byzantium paid Russia great contribution. The treaties resolved the issue of the possible capture of ships of one of the parties, the murder of a foreign citizen, the escape of a slave, and so on. It should be noted that the treaties of the Byzantine Empire with other states were made in two copies with the same content both in Greek language and the language of other contracting party. Both parties made an oath concerning observance of the treaty: the Greeks under the Christian law, while the Russians swore in the name of Perun and Veles, and laid swords. In the treaties of 907-911, Kievan Rus serves as a state that is not inferior to Byzantine culture, has a political organization and well-established law. This is the first document in which Eastern Slavs come to the historic stage as equal to the Greeks.

In the structure of state institutions of Kievan Rus, the Grand Prince of Kiev played the main role. Only a family member of Volodymyr the Great could be a prince that contributed to the idea of unity of Russian land. However, the lack of stable forms of succession caused a constant struggle for Kievan throne. In that struggle someone who was stronger or who was supported by veche often won, but not anyone who had more rights.

The competence and power of the prince were unlimited and depended on his authority and the real power which he relied on. In fact, he was a military leader. He initiated military campaigns and their organization. The prince's competence also included: administrative management, tax policy, legal proceedings, international relations, etc. The Grand Prince of Kiev had an influence on church matters as well.

Prince's druzhina (a fellowship) was the main military force of the prince. It was connected directly with the prince. He kept druzhina, provided with weapons, horses, clothes. The senior members of druzhina received land plots as remuneration from the prince, and the junior members of druzhina received a share of the war booty. The druzhina was engaged in collecting tribute, performing police functions, was also an 
advisory body under the prince. Therefore, the prince, as a rule, agreed with his druzhina the most essential issues of the state life, and the ways of their solving.

An integral participant of the prince's management was the boyars' council. A moral obligation of the prince was to take some advice from senior members of druzhina, and from boyars later on. They could refuse to obey if the prince decided to do something without consulting them. However, in spite of the moral obligation of meetings with the boyars' council, their actual existence, they did not become a state institution in Kievan Rus with a certain composition, competence, functions, but they gathered from time to time at the request of the prince.

The prince appointed all the officials personally and they reported for their actions or inaction to him only. The first place among the government was held by the chancellor-stamp man, who not only affixed a stamp on prince's orders, but also performed complex diplomatic orders, and also executed military functions.

The main official of the prince was tysyatsky (a thousandman), who had been elected by veche before the prince reign, and then turned into a prince official. He was responsible for solving economic, financial, business issues, as well as governed the city military troops.

Judgment in Kievan Rus was carried out on the basis of city "truths", legal codes existed in an oral form. Such law was called the customary law.

The first written code in Russia was the "Yaroslav's Truth", which was based on verbal "truths" of Oleg, Igor, Olga, Volodymyr. Judicial functions were performed by teunos and posadniks. Lower court officials called vyrnyky, metalnyky, mechnyky, and otroky.

A significant role in the management of the state was played by single princes controlling the territories of appanage principalities, protecting them from the encroachment of neighbors and nomads, collecting tribute and sending it to Kyiv. The appanage princes had their druzhina and, as a rule, participated in the military campaigns of the Grand Prince of Kiev as the leaders of druzhina.

It is worth keeping in mind that the prince was invited to reign by the city "veche". "Veche" could dismiss the prince. The Kievan prince asked (offered) veche's consent for the reign of his sons, agreed the above mentioned issues with the "best people", and came to an agreement with them. 
A constant prince's concern was to expand the boundaries of the state and strengthen it. Oleg tamed Polans, Severians, Drevlyans, Radimichs, and forced them to pay tribute, and he was fighting with Ulichs and Tivertsi. Igor continued Oleg's activity, taming the tribes of Tivertsi and Ulichs, and attached a large territory between the Dniester and the Danube to the Kiev state. ${ }^{5}$ Princess Olga laid the foundations of new towns and villages. She introduced the procedure for collecting tribute concerning the time and place of collection and its quantity. She established that $2 / 3$ of the tribute is sent to Kyiv for national needs, and 1/3 to Vyshgorod for the needs of the prince's court.

Olga's successor, her son Sviatoslav, began his reigning by campaigns on the Oka and the Volga, where he defeated Vyatichs, Kama Bulgarians in 964 and in 965 destroyed the Khazar Kaganate. Sviatoslav first carried out the division of the state into separate principalities, having appointed Yaropolk in Kiev, Oleg in Ovruch, and Volodymyr in Novgorod. It is the appointment of Volodymyr in Novgorod that united him with Kiev and thus united the Northern and Southern Rus. ${ }^{6}$

The reign of Volodymyr the Great brought the prosperity to Kievan Rus. Its territory was extended to Transcarpathia and Krakow. Volodymyr defeated Pechenegs, replaced the Varangian druzhina with the Rusychi, and distributed the land between twelve sons, keeping Kiev for himself. The tribal names disappeared; the names of Kievites, Smolyani, Pereyaslavtsi, and Chernigivtsy appeared. ${ }^{7}$

Volodymyr comes to the understanding that besides power there should be an additional, unifying the state, power. And he sees such force in religion. At first Volodymyr preferred the pagan religion. In an effort to unite the numerous tribes of Kievan Rus, he put the statues of their gods in the Pantheon and demanded the official recognition of these gods, bringing them a sacrifice. However, the tribes continued to pray to their gods: respect, appreciation and fear of these gods they placed higher than relations with the Grand Prince of Kiev.

Volodymyr understood that pagan religion can not unite his state, playing the role which had been played by Christianity for the establishment of neighboring European states. At that time, Bulgaria (864), Czech Republic (928-935), Poland (962-992) were baptized. It was

\footnotetext{
${ }^{5}$ Б. Д. Греков. Киевская Русь. - М. - 1953. - С. 456.

${ }^{6}$ М. Грушевський. Історія України-Руси. К. Наукова думка, 1992. - Т. І. - С. 459.

${ }^{7}$ Д. С. Лихачев «Повесть временных лет». - М., 1950. - Т. ІІ. - С. 328.
} 
clear for Volodymyr that his state only accepting Christianity could enter as an equal member to the circle of European states. ${ }^{8}$

Such circumstances appeared in 987 when the Byzantine commander Bardas Phokas opposed Emperors Basil II and Constantine. They asked Volodymyr for assistance. Volodymyr agreed to support them, but on condition of his marriage to their sister Anna. They, in turn, set preconditions for the wedding, namely, Volodymyr's christening. He sent 6,000-army to the emperors to help, which defeated Bardas Phokas' army. However, the emperors changed their mind in relation to their promise. Then, after a long siege, Volodymyr captured a Byzantine colony in Crimea - Chersonese, threatened them to go to war against Byzantium. This fact forced the emperors to fulfill the condition of their agreement. After Volodymyr's christening, he was married in church with Anna, the sister of the emperors, at the end of 987 . In the summer of 988 , Rus was baptized. $^{9}$

Baptizing of Rus strengthened the princely power through the receipt of the title of Caesar (tsar). The princely power became power from God. Christianity brought the "law of God" to Rus as well as Byzantine education and culture. Volodymyr as a Christian and a ruler of the Christian state became in line with the most prominent rulers of Europe. He married his children with members of the families of European monarchs and thus strengthened the international authority of Kievan Rus.

During his rule, Yaroslav the Wise continued the activities of Volodymyr the Great. After completing the struggle with Svyatopolk, he started returning the western lands of Kievan Rus. In 1022, he returned Berestia back; in 1031 he went to Poland and took the city of Cherven. M. Hrushevsky believes that Yaroslav returned all the lands of the PolishUkrainian border. Yaroslav extends the boundaries of the state towards the Finnish lands.

In 1130, he went to war to Chud and consolidated his power over the Lake Peipus, and he builds the city of Yuriev over the Western Dvina (now referred as Tartu).

In 1036 Yaroslav totally defeated Pechenegs, after which they left the Black Sea steppes and traveled over the Danube. ${ }^{10}$

\footnotetext{
${ }^{8}$ Е. Вінтер. Візантія та Рим у боротьбі за Україну. - Прага, 1944. - С. 13-14.

${ }^{9}$ Назарко У. О. Святий Володимир Великий. Володар і хреститель Русі-України. - Рим. 1954, с. 83.

${ }^{10}$ Повесть временныъ лет под ред. В. П. Андриановой -Перет. Статьи Д. Лихачева. - М-Л. 1995, Т. 1. - С. 99-100; М. Грушевський. Історія України-Руси. - К, наукова думка. - 1992, Т. 1. - С. 22.
} 
Following Volodymyr, Yaroslav arranges diplomatic relations with the rulers of the Western European states primarily through the marriages of his sons and daughters with members of their families. During Yaroslav reign a widespread development of various crafts, grain production, and trade was taking place. The church matter was finally formed. In 1051, following the order of the prince, bishops gathered in Kiev and elected "Ilarion Rusin" as Metropolitan, a priest of the Church of the Savior on Berestov church - a highly educated erudite and a brilliant speaker. His "Word of Law and Grace" proclaimed in the Church of the Tithe, is an outstanding work, which had nothing equal in the Greek Church of that time. ${ }^{11}$ The reign of Yaroslav is characterized by an exceptional rising of art.

Volodymyr Monomakh made the last attempt to unite the land of Kievan Rus around Kiev. During his reign from 1113 to 1125 3/4 of the territory, Pereyaslav, Smolensk, Turovo-Pinsk was under the authority of Volodymyr.

Volodymyr ruled the state together with his sons, who had not yet been released from the witness. But he held other princes in witness too. He gave new articles of "Russian Truth", arranged the loan matters and set the amount of legitimate interest. ${ }^{12}$ Volodymyr Monomakh's authority was so high that he passed the throne to his eldest son Mstislav without any obstacles.

Mstislav I, following the reign of his father in 1130, captured the principality of Polotsk. There were only $1 / 4$ of lands of the entire territory of Kievan Rus beyond his power. Since his death in 1132, the period of Ukrainian history ended, when the struggle for concentration of lands around Kyiv was still taking place with separatism, the tendency to separate the lands from the state of Kievan Rus. However, the principle of separatism beat the desire to create a powerful centralized state in a short time.

What was Kievan rus like as a state at that time?

Even in accordance with modern requirements, it had all the signs of a sovereign state at that time. Kievan Rus had a territory within clearly defined boundaries, namely, from the Carpathians and Volyn in the West to the Don and the Volga in the East.

\footnotetext{
${ }^{11}$ Н. Полонська-Василенко. Історія України. - К., Либідь, 1992. - Т. І. - С. 130.

${ }^{12}$ М. Грушевський. Історія України-Руси. - К., Наукова думка, 1992, Т. II. - С. 180-181.
} 
From Ladoga, Yuriev (Tartu), the Lake Peipus in the North to the Ros River in the South.

Kievan Rus was not a union of tribes, but a territory with an administrative division into separate principalities with their capitals. And people were not called Polans, Severians, Ulychs, but Kyivites, Novgorodians, Pereyaslavtsi, and Chernigivtsy. They were identifying themselves as Russian people more and more.

The Great Prince of Kiev and appanage princes had druzhinas for the protections of boundaries from the outside enemy.

There was an own tax system - the collection of tribute such as furs, honey and wax, which were sold on the Eastern markets. For the money earned, the prince kept his druzhina satisfying other state needs.

There was an own court system, where the trial was carried out in accordance with the "Yaroslav's Truth".

Kievan Rus had its own money. These were silver hryvnas and gold coins depicting a prince and a trident state emblem.

The public power existed in Kievan Rus. The state was headed by the Grand Prince of Kiev, appanage princes in certain lands, there were "veche" in the cities and "verv" in villages.

In spite of constant wars with steppe nomads, civilization and culture developed, cities and villages grew, crop areas were expanded, through nomadic life of the steppe horde the trade continued to reach the sea, and the development of culture was in progress.

The impulse for the disintegration of Kievan state was its division between the sons and numerous relatives of Volodymyr Monomakh and the lack of clear laws on the throne succession: whether from father to son, or from brother to brother.

In 1130s, Novgorod was separated from Kyiv. Even earlier the Polovtsian principality had been separated. In 1150s a separate TurovPinsk principality was formed. Then Volyn and Galicia were separated. Then the Pereyaslav, Smolensk, Chergihiv and Nadvolga principals were separated. By the end of the 12th century, only Kyiv region and its suburbs remained from the great state of Volodymyr the Great and Yaroslav the Wise. The title of the Grand Prince continued to exist, but it gradually turned into something nominal. The Grand Prince had neither power nor real strength. 
The tributes obtained from various principalities were stopped. The Grand Prince could not gather enough army that needed to protect the borders, as it depended on those princes, who influenced the state disintegration. The desire of more and more landss to create their own states with their own dynasties had intensified. This trend was consolidated by the Lubetsky congress of princes in 1097. That resulted in the fact that the Grand principalities were divided into numerous small, poor principalities, which were incapable of state life in full measure.

All the above mentioned led to the decline of the Grand prince's authority as well as to the weakening of Kievan state.

Local government in Kievan Rus appeared long before the Old Russian state. The available historical sources bring to us the first reliable recollections about the people's rule in the Eastern Slavs. These reports of people's assemblies in the Eastern Slavic tribes are dated from the middle to second half of the 6th century A.D.. Byzantine historians Prokopius of Caesarean Mauritius Meander stated that the Slavs lived under the conditions of the tribal regime, and all their matters, good or bad ones, they solved together. Prokopius, for example, wrote that the Slavs and Antas were not ruled by anyone alone, but they were governed by people's assemblies for along time. However, in times of general danger, they chose the king ("reks"), whose authority was recognized by the entire public. ${ }^{13}$

This Byzantine historian left a description of public assemblies for us, which addressed the most important issues of their existence in the Antes such as the unification of all forces for war, relations with neighbors, election of leaders, etc.

And only at the end of the 9th century, within the East Slavic settlement, the oldest socio-political organization appeared which we can study in more detail using a variety of written sources. The first written mention of local self-government bodies in Kievan Rus dates from 983. Namely, in the "Tale of Bygone Years", a description of such people's assembly is given. In this invaluable source it is noted that the decision was made by voting, by drawing lots.

Along with the head of the principality government is a "veche" gathering of the capital city. Regional self-government existed in the form of veche assemblies. The Veche ${ }^{14}$ is an "assembly" of all citizens. Veche

${ }^{13}$ Полянська-Василенко М. Історія України: У 2 т. Т. I. До середини XVII століття. - К.: Либідь, 1992. - C. 68.

${ }^{14}$ Слово «віче» народилося у праслов'янські часи і означає «рада». 
decisions have full legal force, but they must be adopted unanimously. In the absence of unanimity, the veche ends with no result, and sometimes with a common quarrel or even a fight.

Between these two bodies, the "prince-veche" there was not any restriction: everything that the prince could do, the veche could do as well. The veche, inviting the prince, concluded, as the chronicle writes, a "ryad" (literally "a row") with him, that is, a formal agreement.

During the times of Kievan Rus in the 10-13th century, various forms of local self-government found their manifestation in veche. For the veche organization of administration, the more or less clear division of powers between the prince and free people of the region was typical. It is significant that people did not imagine a state and socio-political life without the prince. "It's hard for the Kievans, they had no prince at all", wrote the Kyiv chronicler in 1155. Even more vivid events took place in Galicia: the nobility did not imagine life without a prince even there and in difficult conditions of struggle with Danil Galich invited, at first, Igorevichi, then the Hungarian king.

Veches invited or dismissed the prince; they were in charge of war and peace, took part in the formation of administrative and judicial bodies, etc. In Kiev, the chronicle under year 1024 gave the first hint about the veche: Mstislav gained a victory over Yaroslav, but he did not take the throne of Kiev because the Kievans did not want him. In the year of 1068 Kievans - against all rights - elected prince Vseslav of Polotsk, from another dynasty. In 1113 - again contrary to the right of the throne succession - they invited Vladimir Monomakh. And in 1151, the Kievans did not want to have Prince Vyacheslav, but recognized his brother Izyaslav: "We do not want him, you are our prince".

Princes, mostly, recognized the veche's right to elect, approve or, conversely, dismiss. Izyaslav II behavior is very demonstrative: in the fight against Yuriy Dolgoruky for Kyiv, he appealed to Kievans several times for support and did not blame them for refusal to fight with "Monomakhovich", that is, Yuriy. Even when, having been in the struggle, the Kievans asked him voluntarily give way to Kiev to Yuriy in 1149 , so Izyaslav left it obediently.

The princes recognized the will of the veche as a certain imperative of "given": Izyaslav Davidovich explained to Yuri Volodymyrovych that "he did not go to Kiev himself, but the Kievans put him on the throne". 
The prince elected by people had "to make an agreement" with them, to conclude a "riad". When Prince Rostislav, who was elected in 1154, went to the campaign, not concluding the "riad", then boyars reminded him that it was better "to receive an approval from people", and they were right, because he lost his throne.

We do not know exactly the content of these "riad". We must suppose that it was an agreement not to give the tiuns a right to administer justice themselves, to go deep into all matters. At least the "riad" with Igor looked that way in 1146. Volodymyr Monomakh gave in his "Preachment" the theory of duties of the prince in relation to people. He taught his sons to go deep in all the details of administration themselves.

The Veche in Ukraine did not acquire such definite forms as it was in Novgorod or Pskov. It had neither clearly defined competence nor the order of convocation. Sometimes the prince convened the veche. In 1147 Izyaslav convened the veche to announce about his agreement with Metropolitan. Danylo Galytsky, during the struggle for Galich, convened the veche in Galich and asked if he could have support from Galich citizens. Many examples like this can be given. Even more cases are known when the veche assembles without the will of the prince, spontaneously. So, it was the same in 1068 in Kiev, and in 1097 in Volodymyr. In the latter case, the "Volodymyrske" veche forced David to extradite the boyars to Rostislavichi who were involved in the blindness of Prince Vasilko.

And yet, it should be emphasized that the veche remained an accidental phenomenon, it did not obtain the nature of a state institution, Kyivan veche did not reach the level of development inherent in Novgorod veche. ${ }^{15}$

It is a well-known fact that the veche democracy was the most developed in the North of Kievan Rus, in Novgorod. Here we can find the sprouts of people's self-organization bodies. We should note that Novgorod had a developed system of local self-government. The city was divided into five parts such as administrative districts. Each of them had its own territorial "end" (kontsy) veche. Everyday matters were solved at these meetings, as well as tactics of behavior were developed at the general city veche. Officials and administrative bodies were elected there - the end elder and the end council. It should be noted that end

\footnotetext{
${ }^{15}$ С. Томасівський. Історія України. Старинні віки і середні віки. - Мюнхен, 1948. - С. 84.
} 
system overlapped on a more ancient hundredth (sotnia) system. Novgorod was also divided into ten hundreds, and hundreds was further divided into "streets". Elected hundreds and street elders were at the head of them. According to archaeologists, elections at this level were carrying out not by shouting, but by submitting special "ballots" called the Birch bark letters. ${ }^{16}$

We should note that despite the significant, sometimes overwhelming role of the boyar aristocracy, Novgorodians had the opportunity to strictly control the actions of the elected officials. At the request of one of "ends" the veche could make a decision on the displacement of any official and, if necessary, their punishment. Many times the princes were dismissed, including Alexander (Nevsky), posadniks were dismissed for excessive extortions and, even, the archbishop for bribing during the election. ${ }^{17}$ Such actions were not possible without activity of "end" and street elders, who represented ordinary people of Novgorod.

Many facts prove that the veche made decisions on the issue of the prince's military troops, namely, the warriors. So, veche decided to give warriors or not. During the struggle of Izyaslav II with Yuri, the Kyivites stated, for example, that, despite the love to Izyaslav, they would not go against "Monomakhovych-Yuri", but they would go even with their children against Olgovichi.

The economic basis of city self-government was city corporate property, including land. The city community itself established rules of economic management, city taxes, payments and other duties.

Tysiatskii (a thousandman) was at the head of a large urban community, who also governed the people's military troops. The community council managed the daily life of Kyiv. It included tysiatskii (a thousand), sotskii (a hundred), and representatives of the wealthy elite. The activities of the city council are repeatedly mentioned in the chronicles. The meeting of the inhabitants of the main city was the only one in the local principality. It equally concerned the capital city of Kiev as well.

Cities in Kievan Rus were divided into private-ownership and free ones. Private ownership cities, as a rule, are small city centers, fortresses and castles belonging to princes or boyars. In free cities, the prince did not have the right to sit on the throne without consent of the community. As a

\footnotetext{
16 Янин В. Л. Я послал тебе бересту... М., 1965. - С. 156.

${ }^{17}$ Цей тлін Р. С., Сергеев С. А. Историяместного управления и муниципального самоуправления в России: Учебное пособие. - Москва: Омега - Л., 2006. - С. 19.
} 
rule, large cities, centers of lands and principalities belonged to them. In Southern Rus from the second half of the 12th century, first of all, the capital city of the state Kyiv, and, also, Volodymyr, Galych, Chernigov, Lutsk (Luchevsk) Peremysl were such cities, which represented significant trading cities. ${ }^{18}$

According to some scholars, the attack of princes on the community city liberties resulted in an opposition that turned into a struggle for full judicial and tax immunity, that is, the right to collect taxes and judge citizens according to their own laws. These collections of legal acts were city "Truths", legal codes that existed in oral form. This law is called the customary law. The struggle of citizens for their rights and freedoms resulted in the fact that the first written code in Rus was granted to the city community and it was called "Yaroslav's Truth".

It was based on the oral Truths: "The Russian Act" of Oleg and Igor and "Law of the Earth" by Volodymyr Sviatoslavich. ${ }^{19}$

Thus, the first mention of the people's assemblies in the Eastern Slavs belonged to about the middle of the 6th century A.D. These tribal assemblies gradually turned into veche, where the most important issues of life in the region, the principality or the city were solved. As for Kiev, it could decide the issues on the election or the dethronement of the prince. At the time of Rus separation, no prince could sit on a throne of Kyiv without the consent of the community.

Having become stronger, the princely government is attacking the rights and liberties of city dwellers. However, the city dwellers have secured their rights to judicial and tax immunity in the city "Truth" and the conclusion of special agreements with the princes, called "riad". However, one should not exaggerate the value of these documents. However, city democracy was limited in nature, since all the "best men" governed everything at assemblies (veche): the boyars and prince's troops (druzhina), merchant and artisan management elite, not taking into account that all citizens of a free city participated in city councils formally.

\footnotetext{
${ }^{18}$ М. Картер. К вопросу о Киеве VIII-XI вв. Кратки сообщения о докладах и Полевих исследованиях института Ист. Мат. Культуры. Вып. VI, выд. Акад. Наук ССCР. - Москва, 1940.

193 історії самоврядування та демократії у Києві (від княжої доби до нашого часу) : Посібник для старших класів: Котляр М. Ф., Левітас Ф. Л., Несторенко Л. С., Рубців В. П., Семашко О. М., Тараненко М. Г., Ткачук А. Ф., Чухліб Т. В. - К., 2000. - С. 56-57.
} 
"Ukrainian cities and, mainly Kiev, experienced the same process of struggle against princely power and patricianism that took place in the Western Europe and led to the formation of free city communities in France, Germany, and Italy. From the short words of the chronicle, one can conclude that such a struggle was "the first revolution of 1068", the death of Izyaslav, the uprising and suppression of him by Mstislav. The uprising of 1113 was even bigger". ${ }^{20}$

From the middle of 12 th century the struggle of middle citizens to the rights of the city became stronger. We know about the agreements "riads" of the prince with people dated 12 th century. ${ }^{21}$

The subject of rural self-government was a rural community (verv). It united the dwellers of several neighboring villages. This is probably due to the fact that the villages were small, their people were united in larger communities to solve common issues and protect their interests. Verv had a small land in corporate ownership, represented its citizens in their relations with other city dwellers, feudal lords, and state power.

In the 12-13th centuries the extension of boyar's landownership took place, which led to a decrease in the number of independent peasant communes. On the contrary: the number of laborers, peasants, dependent on landowners who worked on the boyars' land, being free, are increasing.

It should be noted that "veche" and "verv" were of great importance for the formation of the statehood of Kievan Rus, being the support of the prince in solving, first of all, the issues of war and peace, other significant state issues, large and small problems of cities and villages.

At the same time, "veche" expressed the interests of different segments of the city population, to whom the prince had to pay. But in time, prosperous citizens or "the best people", "muzhy" whose interests often did not coincide with the interests of the prince influenced the adoption of "veche" decisions more and more. And then "veche" was used to fight the prince. At the end of the 12th century, at the beginning of the 13th century, the prince's "veche" was controlled by the boyars and local merchants. There were occasions when the "veche" was convened by a prince or "best people". The "veche" broke the succession matters of the princes more and

${ }^{20}$ Полянська-Василенко М. Історія України: У 2 Т. Т.1. До середини XVII століття. - К.: Либідь, 1992. - C. 221-222.

${ }^{21}$ Тихомиров М. Н. Древнерусские города. - Москва, 1956. - С. 141-147. 
more, chose "the dearest" people, opened their city gates and expelled from the city "hated" people. All this weakened the prince's power.

The weakness of the city "veches" was in the fact that they were not a systematic phenomenon, convened from case to case. Thus, they did not acquire the nature of constantly functioning state institutions. And they did not form the foundations for parliament, as happened in England after the adoption in 1215 of the "Great Charter of freedoms."

Based on all the above mentioned we can affirm that this was one of the reasons for the decline of Kievan Rus.

\section{CONCLUSION}

Prosperity of the Kiev state took place during the reign of princes Volodymyr the Great and Yaroslav the Wise. At that time Kievan Rus was the greatest state in Europe. It was a centralized state governed by the Great Prince of Kiev with unlimited powers. Druzhina was the main military force of the prince. Boyars' council was the advisory body served to the prince. Judging was carried out according to "Yaroslav's Truth". The self-government bodies at the local level were "veche" in the cities and "verv" in the villages.

Kievan Rus gained fame by a world military campaign of princes to Byzantium and the conclusion of agreements with the Byzantine emperors favorable for Rus, campaigns on Khazaria, Bulgaria, in Polish and other lands. That was the time for the expansion of the state borders, the conquest of neighboring tribes, the gathering of land around Kiev, their integration into the Kiev state.

The activities of Kiev princes significantly expanded the political relations of Kievan Rus with the Western Europe. In addition to Byzantium, Poland and Norway, primarily due to dynastic marriages, close ties with Germany, France, Hungary and other states were established.

The baptism of Rus, which brought the law of God to the Rus people and placed them in one line with the most powerful European states, was an event of historical significance. In Rus, churches and monasteries were built, under which schools were created.

The internal policy of the Great princes, in its implementation, was focused on the reorganization of administrative management and troops, on the development of agriculture, livestock and beekeeping, pottery and 
woodworking, the development of crafts of local and foreign trade, education, culture and art.

The intensive process of Kievan Rus disintegration began when Yaroslav the Wise divided the state between his sons and many numerical relatives in the absence of strict standards of succession. With the win of the hereditary throne succession principle of the patrimony over the system of seniority for princely families, it becomes increasingly apparent that their future is associated with appanage lands, and not with Kiev, for which continued struggle has taken place. The princely dynasties lost their sense of solidarity, plunged into minor disputes, began to use military force to resolve them.

The weakening of the state led to the fact that the Polovets attacks became a constant phenomenon. The Southern part of Kyiv region was devastated.

Along with constant problems existed, the economic problems existed too. Foreign trade, which was one of the foundations of the state economic prosperity, declined not only as a result of capturing steppes by nomadic tribes, but also because the Crusades directed the trade routes to the Mediterranean Sea. They opened the sea routes and the East, directly linking the Western Europe with Asia, Byzantium for Italian, French, and German cities. And Kievan Rus was left aside the established trade routes. This led to the impoverishment of the main center of the state, namely Kyiv region, and became one of the reasons for the decline of Kievan Rus, but internal problems would not lead to the death of the state. The Tatar Mongol invasion led to its final destruction.

\section{SUMMARY}

The article deals with the historical events associated with the emergence of the state of Kievan Rus, its appearance on the world stage as well as the activity of the Grand princes to expand the boundaries of the state, conquer the neighboring tribes, unite them around Kiev and integrate them into the Kievan state. The processes of state power formation, its structure, meaningful activity of the authorities are highlighted. The role and place of local self-government in the life of Kyiv state, "veche" in cities and "verv" in villages, are shown. Conditions of prosperity and causes of decline of Kievan Rus are revealed. 


\section{REFERENCES}

1. Брайчевський М.Ю. Походження Русі, - К., Наукова думка, 1968. - 221 ст.

2. Вінтер С. Візантія і Рим у боротьбі за Україну. - Прага, 1944. $425 \mathrm{c}$.

3. Греков Б.Д. Борьба Руси за создание своего государства. - М., 1954. -392 c.

4. Грушевський М.С., т. II - К., Наукова думка, 1992. - 633 с.

5. Ключевский В.О., Курс русской истории. Часть I. - М., Мысль, 1987. - 440 с. $519 \mathrm{c}$.

6. Крип'якевич І.П., Історія україни. - Львів, Вид. «Світ», 1990. -

7. Лихачев Д.С. «Повесть временных лет»- М., 1959. - 506 с.

8. Мавродин В.В., Образование древнерусского государства, M., 1946. - $276 \mathrm{c.}$

9. Назарко I. о., Святий Володимир Великий і Хрещення Руси України, - Рим, 1954. - 296 с.

10. Полонська-Василенко Н., Історія україни, т. II. - К., Либідь, 1992. $-588 \mathrm{c}$.

11. «Повесть временных лет» / под ред. В. П. АдриановойПеретц. Статьи и комментарии Д. Лихачева,т.т. I-II. - М-Л. 1950. $534 \mathrm{c}$.

12. Рыбаков В.А., Древняя Русь., - М., Сов. Археология, 1953. $327 \mathrm{c}$.

13. Соловьев С.М., История России с древнейших времен, т. 1-2. - М., Мисль, 1998. - 797 с.

14. Субтельний Орест., Історія України. - К., Либідь, 1993 - 717 с.

15. Татищев В.Н., История России с самих древних времен, т. І. M., 1968. -472 c.

16. Тихомиров Я.Н. Древнерусские города, - М., - 1956. - 472 с.

\section{Information about the author: Malchyn Yu. M.}

Doctor of Historical Sciences

Professor at the Department of Philosophy and History V. I. Vernadsky Taurida National University, 10, Peremogy avenue, Kyiv, Ukraine 